\title{
Thermochemical Energy Storage Performance of Zinc Destabilized Calcium Hydride at High-Temperatures'
}

Received 00th January 20xx, Accepted 00th January 20xx DOI: $10.1039 / x 0 x \times 00000 x$

\author{
Sruthy Balakrishnan, ${ }^{a}$ M. Veronica Sofianos, ${ }^{a, b *}$ Terry D. Humphries, ${ }^{a}$ Mark Paskevicius, ${ }^{a^{*}}$ and Craig \\ E. Buckley ${ }^{a}$
}

$\mathrm{CaH}_{2}$ has 20 times the energy density of molten salts and was patented in 2010 as a potential solar thermal energy storage material. Unfortunately, its high operating temperature $\left(>1000^{\circ} \mathrm{C}\right)$ and corrosivity at that temperature make it challenging to use as thermal energy storage (TES) material in concentrating solar power (CSP) plants. To overcome these practical limitations, here we propose, the thermodynamic destabilization of $\mathrm{CaH}_{2}$ with $\mathrm{Zn}$ metal. It is a unique approach that reduces the decomposition temperature of pure $\mathrm{CaH}_{2}\left(1100^{\circ} \mathrm{C}\right.$ at 1 bar of $\mathrm{H}_{2}$ pressure) to $597{ }^{\circ} \mathrm{C}$ at 1 bar of $\mathrm{H}_{2}$ pressure. Its new decomposition temperature is closer to the required target temperature range for TES materials used in proposed thirdgeneration high-temperature CSP plants. A three-step dehydrogenation reaction between $\mathrm{CaH}_{2}$ and $\mathrm{Zn}$ (1: 3 molar ratio) was identified from mass spectrometry, temperature-programmed desorption and in-situ X-ray diffraction studies. Three reaction products, $\mathrm{CaZn} \mathrm{n}_{13}, \mathrm{CaZn_{11 }}$ and $\mathrm{CaZ} \mathrm{n}_{5}$, were confirmed from in-situ X-ray diffraction studies at $190{ }^{\circ} \mathrm{C}, 390{ }^{\circ} \mathrm{C}$ and 590 ${ }^{\circ} \mathrm{C}$, respectively. The experimental enthalpy and entropy of the second hydrogen release reaction were determined by pressure composition isotherm measurements, conducted between 565 and $614^{\circ} \mathrm{C}$, as $\Delta H_{\text {des }}=131 \pm 4 \mathrm{~kJ} \cdot \mathrm{mol}^{-1} \mathrm{H}_{2}$ and $\Delta S_{\text {des }}$ $=151 \pm 4 \mathrm{~J} \cdot \mathrm{K}^{-1} \mathrm{~mol}^{-1} \mathrm{H}_{2}$. Hydrogen cycling studies of $\mathrm{CaZn_{11 }}$ at $580^{\circ} \mathrm{C}$ showed sufficient cycling capacity with no significant sintering occurring during heating, as confirmed by scanning electron microscopy, demonstrating its great potential as a TES material for CSP applications. Finally, a cost comparison study of known destabilized $\mathrm{CaH}_{2}$ systems was carried out to assess the commercial potential.

\section{Introduction}

The primary objective of the next-generation concentrating solar power plants (CSP) is to provide continuous electrical power supply at a $40 \%$ cost reduction in comparison to the plants currently operating. ${ }^{1}$ This cost reduction can be met due to the higher power cycle efficiency achieved in a $600-800{ }^{\circ} \mathrm{C}$ temperature range by replacing a conventional steam power engine with a Stirling engine. ${ }^{2}$ Specifically, the US Department of Energy released the Sun Shot research programme with a target to develop thermal energy storage (TES) materials that operate above $600{ }^{\circ} \mathrm{C}$, have $\geq 95 \%$ exergetic efficiency and cost less than $\$ 15 / \mathrm{kWh}_{\mathrm{th}}$ by 2030 . Hence, the identification of a cost-

\footnotetext{
a. Physics and Astronomy, Fuels and Energy Technology Institute, Curtin University, GPO Box U1987, Perth, WA 6845, Australia.E-mail: mark.paskevicius@gmail.com b. University College Dublin, School of Chemical and Bioprocess Engineering, Belfield, Dublin 4, Ireland, E-mail: veronica.sofianos@ucd.ie

†Electronic Supplementary Information (ESI) available: Theoretical predictions of possible reaction between $\mathrm{CaH}_{2}$ and $\mathrm{Zn}$ and corresponding $\mathrm{H}_{2}$ wt. \%, vapor pressure curves for pure $\mathrm{Ca}$ and $\mathrm{Zn}$ and calcium zinc alloys as a function of temperature, Rietveld refinement of the diffraction pattern for the as prepared $\mathrm{CaH}_{2}-3 \mathrm{Zn}$. Equilibrium pressure curves of $\mathrm{PCl}$ measurements performed at (a) $614{ }^{\circ} \mathrm{C}$ (b) 600 ${ }^{\circ} \mathrm{C}$ (c) $580{ }^{\circ} \mathrm{C}$ and (d) $565{ }^{\circ} \mathrm{C}$ with $3 \mathrm{~h}$ desorption step sizes. SEM micrographs of the $\mathrm{CaH}_{2}-3 \mathrm{Zn}$ after 10 cycles using backscattered electrons and their corresponding EDS spectra.

See DOI: $10.1039 / x 0 x x 00000 x$
}

effective high-temperature TES material that meets these requirements is both essential and challenging. ${ }^{3-7}$

There are a plethora of known TES materials that can be categorized depending on their heat storage mechanism, storage density and operating temperature. Sensible heat storage materials, such as molten salts, are the most commonly used TES materials in the industry. ${ }^{3}$ Nevertheless, molten salts suffer from several drawbacks such as low energy density $(0.02$ $-0.03 \mathrm{kWh} / \mathrm{kg}$ ), corrosion and limited operating temperature (< $\left.565^{\circ} \mathrm{C}\right) .^{8-9}$ Latent heat storage materials have a higher energy density $(0.05-0.1 \mathrm{kWh} / \mathrm{kg})$ than the sensible heat storage materials, but most of the materials presently studied have issues such as low thermal conductivity, and high thermal losses. 4, 10-11 To overcome these drawbacks, a third category of TES materials known as thermochemical energy storage is gaining increasing popularity due the high energy density $(0.5-$ $1 \mathrm{kWh} / \mathrm{kg}$ ) that these materials possess despite their increased complexity. The superior energy storage properties are based on reversible chemical reactions that take place at high temperatures. ${ }^{12-13}$ At present, six systems, namely hydrides, carbonates, hydroxides, oxides, ammonia and organic are identified as thermochemical TES materials. ${ }^{11}$ The unique property of metal hydrides to absorb and release hydrogen at a specific pressure at high temperatures, makes them the most promising thermochemical system amongst the rest, and thereby meeting the requirements of the next generation CSP 


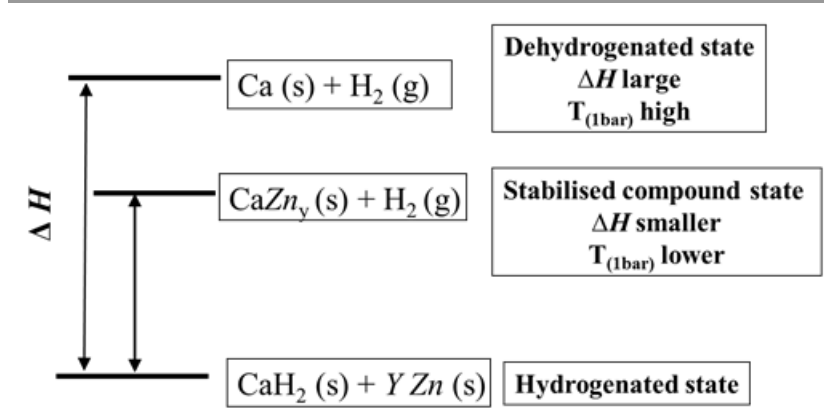

Fig. 1 General enthalpy diagram showing destabilization of $\mathrm{CaH}_{2}$ by adding $\mathrm{Zn}$ through the formation of calcium zinc alloys. ${ }^{24}$

plants. ${ }^{10,14-16}$ Calcium hydride is a promising high-temperature metal hydride due to its: (i) low cost (\$6000/ton) and abundance, (ii) low operating hydrogen pressure at high temperature $\left(1-5\right.$ bar at $1100-1400{ }^{\circ} \mathrm{C}$ ), (iii) high enthalpy of dehydrogenation (207.9 $\mathrm{kJmol}^{-1} \mathrm{H}_{2}$ ), and (iv) high gravimetric $(4939 \mathrm{~kJ} / \mathrm{kg})$ and volumetric energy densities $\left(8396 \mathrm{MJ} / \mathrm{m}^{3}\right) .^{2,17}$ 18 Its high operating temperature $\left(1100{ }^{\circ} \mathrm{C}\right)$, melting point of both $\mathrm{CaH}_{2}$ and $\mathrm{Ca}$ metal are $816^{\circ} \mathrm{C}$ and $842{ }^{\circ} \mathrm{C}$, and expensive tank material requirements to store the corrosive $\mathrm{CaH}_{2}$, are the main factors that limit the use of pure $\mathrm{CaH}_{2}$ as a thermochemical TES material. ${ }^{17}, 20-21$ Thermodynamic destabilization of $\mathrm{CaH}_{2}$ using suitable additives, is one approach for reducing the decomposition temperature of $\mathrm{CaH}_{2}$, and transforming it as a suitable TES material for the third generation CSP plants. ${ }^{22}$

The main novelty of this study lies in the selection of a relatively inexpensive and abundant metal such as zinc $(\$ 1.93 / \mathrm{kg})$, to be used as an additive in order to reduce the decomposition temperature of $\mathrm{CaH}_{2}$ as illustrated in Fig. 1. This method successfully showed by adding $\mathrm{Al}_{2} \mathrm{O}_{3}$ to $\mathrm{CaH}_{2}$, where the enthalpy of the reaction was found to be $\Delta H=100 \mathrm{~kJ} \mathrm{~mol}^{-1} \mathrm{H}_{2}$ at $636{ }^{\circ} \mathrm{C}$ and 1 bar of $\mathrm{H}_{2}$ pressure. ${ }^{23} \mathrm{CaH}_{2}-3 \mathrm{Zn}$ is an alternate system that exploits the feasibility of $\mathrm{Zn}$ as a high-temperature thermochemical TES material for the third generation CSP plants. The aim of this study focused on thermal analysis, and thermodynamic characterization of the $\mathrm{CaH}_{2}-3 \mathrm{Zn}$ system using mass spectrometry, temperature programmed desorption and in-situ X-ray diffraction studies. Its cycling capacity, sample morphology before and after cycling using field emission scanning electron microscopy (FE-SEM) and cost analysis were also investigated and reported.

\section{Experimental Methods}

\section{Sample preparation}

All chemicals were stored and handled inside an Ar filled MBraun unilab glovebox to reduce oxygen $(<1 \mathrm{ppm})$ and water (<1 ppm) contamination. $\mathrm{CaH}_{2}$ (Sigma Aldrich, > 95\% purity powder) and Zn (Chem supply, > 98\% purity powder) were mixed in a 1:3 molar ratio and milled under an Ar atmosphere using an Across International Planetary Ball Mill (PQ-N04), employing stainless steel vials and balls. The mixture was ball milled for 3 hours with a 40:1 ball (equal number of $10 \mathrm{~mm}$ and $6 \mathrm{~mm}$ diameter balls) to powder ratio. The rotational speed was set to $400 \mathrm{rpm}$ with a change of direction every 30 minutes without pausing.

\section{Sample Characterization}

\section{Theoretical Predictions}

The possible reaction pathways between $\mathrm{CaH}_{2}$ and $\mathrm{Zn}$ were predicted using the phase diagram of the Ca-Zn system. ${ }^{25-26}$ The volatility of solid calcium zinc alloys are linked with the vapor pressure of $\mathrm{Zn}$. The vapor pressure of pure $\mathrm{Zn}$ metal and Ca was calculated from room temperature to $1000^{\circ} \mathrm{C} .{ }^{27}$ Vapor pressure data of calcium zinc solid alloys were also derived from Chiotti et al. ${ }^{37}$ and Hodge et al. ${ }^{39}$ and the vapor pressures of eight calcium zinc alloys $\left(\mathrm{Ca}_{3} Z \mathrm{Zn}, \mathrm{Ca}_{5} \mathrm{Zn}_{3}, \mathrm{CaZn}, \mathrm{CaZn}_{2}, \mathrm{CaZn}_{3}, \mathrm{CaZn_{5 }}\right.$, $\mathrm{CaZn_{11 }}$ and $\mathrm{CaZn_{13 }}$ ) were plotted along with pure $\mathrm{Zn}$ and $\mathrm{Ca}$ as a function of temperature in Figure S1. Among the eight solid alloys, $\mathrm{Zn}$ rich alloys have high vapor pressures and are less volatile than $\mathrm{Zn}$ poor alloys at higher temperatures $\left(>600^{\circ} \mathrm{C}\right)$.

\section{Powder X-ray Diffraction}

Ex-situ powder X-ray diffraction (XRD) was used to identify the crystalline materials in each sample. Airtight polymethyl methacrylate domed sample holders were used to avoid oxygen and moisture contamination during data collection. Data were collected using a Bruker D8 Advance Diffractometer with a copper $X$-ray tube $(\lambda=1.5418 \AA, 40 \mathrm{kV}, 40$ $\mathrm{mA}$ ) in the $10^{\circ}-80^{\circ} 2 \vartheta$ range with a $0.03^{\circ}$ step size and 1.6 $\mathrm{s} / \mathrm{step}$ count time. The diffraction peaks were quantitatively analyzed by the Rietveld method $^{28}$ using the Bruker TOPAS Version 5 software. ${ }^{29}$ The structural information was extracted from ICDD PDF4 database and the Crystallography Open Database (COD). ${ }^{30}$

In-situ X-ray diffraction was performed using a Thermo Fisher ARL Equinox 5000 diffractometer $(\lambda=0.7093 \AA$, Mo-K $\alpha, 50 \mathrm{kV}$, $30 \mathrm{~mA})$. The sample was loaded into a quartz capillary tube $(0.7$ $\mathrm{mm}$ outer diameter, $0.01 \mathrm{~mm}$ wall thickness), sealed and then mounted onto a sample holder inside an Ar filled glovebox. The sample was heated from room temperature to $692{ }^{\circ} \mathrm{C}$ using a hot air blower $\left(5^{\circ} \mathrm{C} / \mathrm{min}\right)$ and kept isothermal for 2 hours. Data were acquired on a CPS 120 detector $\left(0-60^{\circ} 2 \vartheta\right)$ with a $60 \mathrm{~s}$ exposure time. The temperature of the hot air blower was calibrated against the known thermal expansion coefficient of both $\mathrm{NaCl}$ and $\mathrm{Ag} .{ }^{31-33}$

\section{Mass Spectrometry}

Temperature programmed desorption-mass spectrometry (TPD-MS) measurements were obtained using a Stanford Research Systems (SRS, RGA-300) residual gas analyzer consisting of a quadrupole mass spectrometer. ${ }^{34} \mathrm{~A} 3 \mathrm{mg}$ sample of pure $\mathrm{CaH}_{2}$ and $\mathrm{CaH}_{2}-3 \mathrm{Zn}$ was placed in a stainless steel sample holder inside a silicon carbide reactor that was connected to the spectrometer. The samples were heated to $850^{\circ} \mathrm{C}$ at $5^{\circ} \mathrm{C} / \mathrm{min}$ under high vacuum $\left(<7 \times 10^{-4} \mathrm{mbar}\right)$. The corresponding analogue scan of partial pressure vs mass to charge ratio was obtained from the RGA software. A K-type 
thermocouple with an uncertainty of $\pm 1.5^{\circ} \mathrm{C}$ was connected inside the $\mathrm{SiC}$ tube to record the temperature of the sample.

\section{Temperature Programmed Desorption and Pressure Composition} Isotherms

$\mathrm{H}_{2}$ sorption properties were studied by Temperature Programmed Desorption (TPD), using a computer-controlled Sievert's apparatus. ${ }^{35} \mathrm{CaH}_{2}-3 \mathrm{Zn}$ was heated to either $630{ }^{\circ} \mathrm{C}$ or $830{ }^{\circ} \mathrm{C}$, with $5{ }^{\circ} \mathrm{C} / \mathrm{min}$ heating rates. The powder mixture was placed inside a stainless-steel sample holder and then loaded into a silicon carbide $(\mathrm{SiC})$ reactor. $\mathrm{H}_{2}$ has a negligible hydrogen permeation through $\mathrm{SiC}$ at high temperatures $\left(>450{ }^{\circ} \mathrm{C}\right)$ and therefore was chosen as the most suitable reactor material for such measurements. ${ }^{35-36}$ The sample temperature was measured using a K-type thermocouple which is kept inside the $\mathrm{SiC}$ reactor and direct contact with the sample. Pressure Composition Isotherm ( $\mathrm{PCl}$ ) measurements of $\mathrm{CaH}_{2}-3 \mathrm{Zn}$ were conducted on the same apparatus to acquire the thermodynamic properties of the dehydrogenation reaction between $565{ }^{\circ} \mathrm{C}$ and $614{ }^{\circ} \mathrm{C}$ with a 1 bar pressure step size and a $3 \mathrm{~h}$ equilibration time per step. $\mathrm{H}_{2}$ desorption and absorption cycling studies were performed on $\mathrm{CaH}_{2}-3 \mathrm{Zn}$ at $580{ }^{\circ} \mathrm{C}$ with a ramp rate of $5{ }^{\circ} \mathrm{C} / \mathrm{min}$. The $\mathrm{H}_{2}$ pressure and equilibration time during desorption was $\sim 0.8$ bar and $3 \mathrm{~h}$ respectively, whereas during absorption it was $\sim 2.8$ bar and $5 \mathrm{~h}$.

\section{Scanning Electron Microscopy and Energy Dispersive X-ray Spectroscopy}

Field emission scanning electron microscopy (FE-SEM) and energy dispersive $\mathrm{X}$-ray spectroscopy were carried out using a Tescan Mira3 integrated with EBSD/EDS Oxford Instrument detectors controlled by the Aztec software. The SEM images of the $\mathrm{CaH}_{2}-3 \mathrm{Zn}$ system before and after cycling were collected using both secondary and back-scattered electron detectors. The SEM samples were prepared inside an Ar filled glove box by placing a small amount of powder onto a carbon tape, and then transferred to the SEM chamber with minimum air exposure.

\section{Results and Discussion}

\section{Theoretical Predictions}

The phase diagram of the Ca-Zn system shows eight different alloys ( $\mathrm{Ca}_{3} Z \mathrm{Zn}, \mathrm{Ca}_{5} \mathrm{Zn}_{3}, \mathrm{CaZn}, \mathrm{CaZn} \mathrm{n}_{2}, \mathrm{CaZn} \mathrm{n}_{3}, \mathrm{CaZn} \mathrm{n}_{5}, \mathrm{CaZn_{11 }}$ and $\left.\mathrm{CaZn}_{13}\right)$ at different molar ratios. ${ }^{25-26}$ Table $\mathrm{S} 1$ indicates theoretically possible reactions between $\mathrm{CaH}_{2}$ and $\mathrm{Zn}$ and the corresponding theoretical $\mathrm{H}_{2}$ wt\%. The vapor pressure of $\mathrm{Zn}$ plays a vital role in the formation and volatility of the solid alloy formation. ${ }^{27,}{ }^{37-39} \mathrm{Fig}$. S1 shows the vapor pressure curve of pure $\mathrm{Ca}, \mathrm{Zn}$ and solid calcium zinc alloys as a function of temperature. It shows that the vapor pressure of pure $\mathrm{Zn}$ is higher than pure Ca until $600{ }^{\circ} \mathrm{C}$, after which the vapor pressure of $Z n$ is less than that of pure Ca. From Fig. S1 and the Ca-Zn phase diagram it can be seen that $\mathrm{Zn}$ rich alloys have higher vapor pressures and hence are less likely to produce vaporized $\mathrm{Zn}$ above $600{ }^{\circ} \mathrm{C} .{ }^{25}$ Moreover, above $\sim 700^{\circ} \mathrm{C}$ no calcium zinc solid alloys exist.

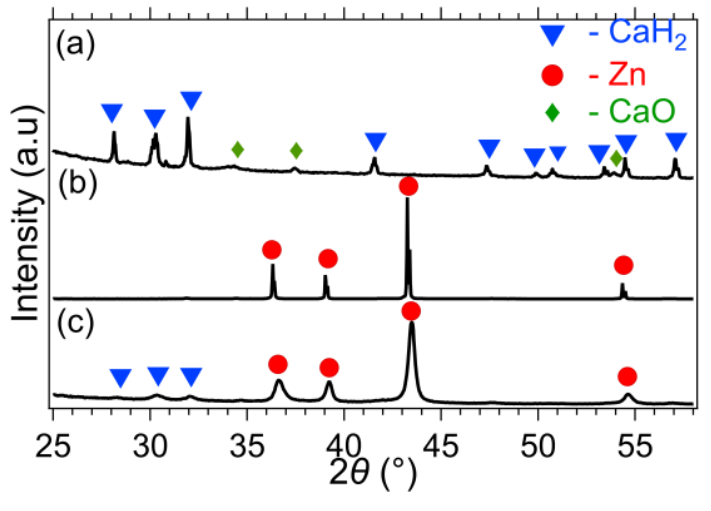

Fig. 2 Ex-situ XRD patterns of (a) $\mathrm{CaH}_{2}$, (b) $\mathrm{Zn}$ and (c) $\mathrm{CaH}_{2}-3 \mathrm{Zn}$ system after ball milling using $\mathrm{Cu} \mathrm{K}_{\alpha}$ radiation $(\lambda=1.5418 \AA$ ) .

\section{Initial Phase Analysis}

The diffraction patterns of as-supplied $\mathrm{CaH}_{2}, \mathrm{Zn}$ and ball-milled $\mathrm{CaH}_{2}-3 \mathrm{Zn}$ are presented in Fig. 2 a, b and c, respectively. Quantitative phase analysis was used to determine the purity of the materials using the Rietveld method. Quantitative phase analysis of the $\mathrm{CaH}_{2}$ reagent shows $\mathrm{CaH}_{2}$ with a negligible amount of crystalline $\mathrm{CaO}$, while the $\mathrm{XRD}$ and refinement pattern for the ball milled $\mathrm{CaH}_{2}-3 \mathrm{Zn}$ only shows $\mathrm{CaH}_{2}(16.5 \pm 0.8$ $w t \%)$, and $\mathrm{Zn}(83 \pm 1 \mathrm{wt} \%$ ) (Fig. $2 \mathrm{c}$ and Fig. S2). This indicates that no reaction occurred between $\mathrm{CaH}_{2}$ and $\mathrm{Zn}$ during ball milling to form a Ca-Zn product as expected by the high required enthalpy of reaction.

\section{The Destabilization of $\mathrm{CaH}_{2}$ Using $\mathrm{Zn}$}

TPD-MS measurements were performed on $\mathrm{CaH}_{2}$ and $\mathrm{CaH}_{2}-3 \mathrm{Zn}$ to compare the $\mathrm{H}_{2}$ gas release profiles as a function of temperature (Fig. $3 \mathrm{a}$ and $\mathrm{b}$ respectively). Due to the high vacuum ( $<7 \times 10^{-4}$ mbar) employed in this technique, $\mathrm{CaH}_{2}$ commenced $\mathrm{H}_{2}$ release at $500{ }^{\circ} \mathrm{C}$ and reached the highest rate of hydrogen release at $600{ }^{\circ} \mathrm{C}$ (Fig. 3 a), with the single decomposition peak indicative of a one-step decomposition reaction. The $\mathrm{H}_{2}$ desorption profile of $\mathrm{CaH}_{2}-3 \mathrm{Zn}$ (Fig. 3 b) consisted of three $\mathrm{H}_{2}$ peaks denoting a three-step decomposition reaction, either due to differing kinetics or thermodynamics of reaction. The first small peak appeared at

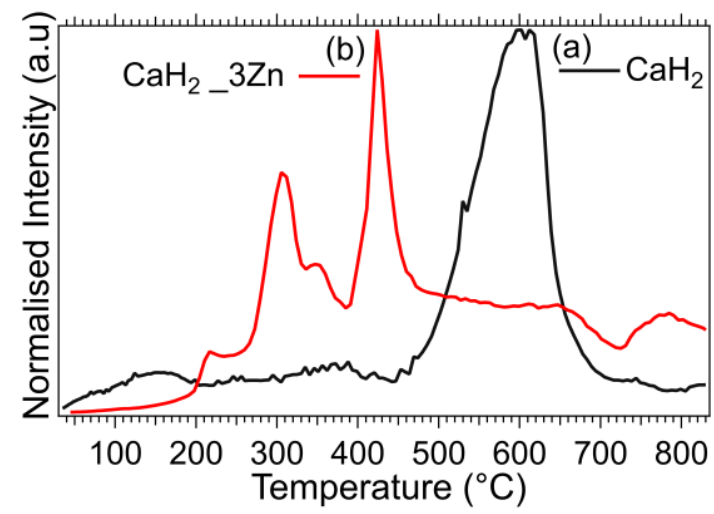

Fig. $3 \mathrm{H}_{2}$ desorption profiles as observed by TPD-MS measurements of (a) $\mathrm{CaH}_{2}$ and (b) $\mathrm{CaH}_{2}-3 \mathrm{Zn}$ while heating under vacuum. 
$200{ }^{\circ} \mathrm{C}$, followed by two high intensity peaks at $300{ }^{\circ} \mathrm{C}$ and 420 ${ }^{\circ} \mathrm{C}$, respectively. $\mathrm{H}_{2}$ was the only gas detected during heating to $800{ }^{\circ} \mathrm{C}$. The three low-temperature decomposition peaks of the $\mathrm{CaH}_{2}-3 \mathrm{Zn}$ sample show that the addition of $\mathrm{Zn}$ thermodynamically destabilizes the $\mathrm{CaH}_{2}$.

\section{Thermal Analysis}

A TPD measurement was conducted on $\mathrm{CaH}_{2}-3 \mathrm{Zn}$ by heating the sample from room temperature to $830{ }^{\circ} \mathrm{C}\left(5^{\circ} \mathrm{C} / \mathrm{min}\right)$, before keeping the temperature isothermal at $830^{\circ} \mathrm{C}$ for 10 hours to check the volatility of the alloy formed (Fig. 4 a). The measurement was commenced under initial static vacuum and reached a maximum $\mathrm{H}_{2}$ pressure of 0.9 bar. After 2 hours at 830 ${ }^{\circ} \mathrm{C}$ the hydrogen pressure began to decrease. The reason for this pressure decrease was due to: (i) zinc evaporation from the alloy as evidenced by zinc metal deposition on the cool regions of the sample cell, and (ii) $\mathrm{H}_{2}$ reabsorption into the zinc-poor calcium metal to reform $\mathrm{CaH}_{2}$. This was confirmed from the sample's ex-situ XRD pattern obtained after the TPD measurement (Fig. 5 a), which comprised of $\mathrm{CaH}_{2}$ and $\mathrm{Zn}$ peaks with no calcium zinc alloy peaks being present. The TPD measurement was repeated with a maximum temperature of $630{ }^{\circ} \mathrm{C}$ and a subsequent isotherm for $10 \mathrm{~h}$. A maximum $\mathrm{H}_{2}$ pressure of 0.58 bar was reached starting from vacuum. Fig. $4 \mathrm{~b}$ illustrates the TPD profile, which exhibits an almost isobaric profile after reaching $630{ }^{\circ} \mathrm{C}$ with reduced $\mathrm{Zn}$ evaporation

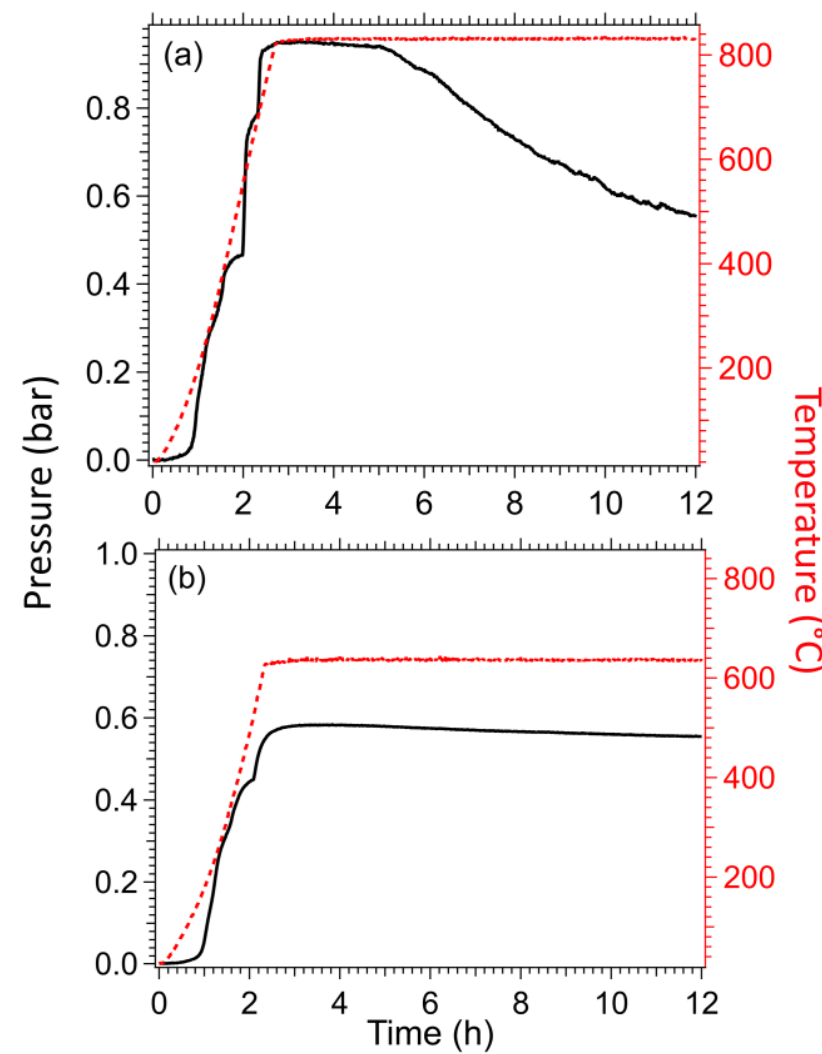

Fig. 4 TPD profiles of $\mathrm{CaH}_{2}-3 \mathrm{Zn}$ from room temperature to (a) $830^{\circ} \mathrm{C}$ and (b) $630^{\circ} \mathrm{C}$. Black solid line $=$ pressure, red dotted line $=$ temperature.

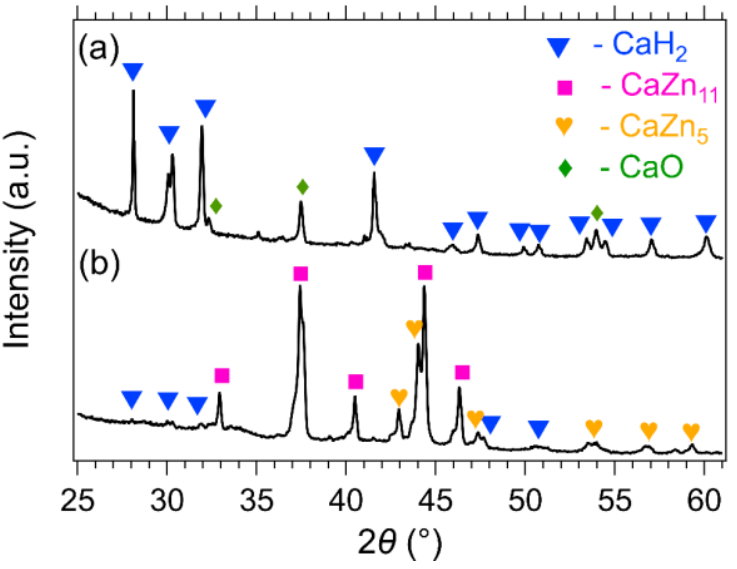

Fig. 5 Ex-situ XRD pattern of $\mathrm{CaH}_{2}-3 \mathrm{Zn}$ after the TPD measurements at (a) $830{ }^{\circ} \mathrm{C}$ and (b) $630{ }^{\circ} \mathrm{C}(\mathrm{Cu} \mathrm{K \alpha}, \lambda=1.5418 \AA$ )

observed in comparison to the data obtained at $830^{\circ} \mathrm{C}$. CaZn $\mathrm{n}_{11}$ and $\mathrm{CaZ} \mathrm{n}_{5}$ alloys were the main decomposition products at 630 ${ }^{\circ} \mathrm{C}$ as confirmed by the sample's ex-situ XRD pattern obtained after the TPD measurement (Fig. 5 b).

\section{Identifying the Reaction Pathway by in-situ X-ray Diffraction}

In-situ XRD data of $\mathrm{CaH}_{2}-3 \mathrm{Zn}$ during thermal ramping under argon is presented in Fig. 6 a and is compared with its differential TPD profile (Fig. 6 b). It is evident from the in-situ XRD patterns that the reaction between $\mathrm{CaH}_{2}$ and $\mathrm{Zn}$ occurs in a three-step reaction between 190 and $590{ }^{\circ} \mathrm{C}$, which is in a good agreement with the TPD profiles. It is clear from Fig. 6 a the three different alloys formed are CaZn ${ }_{13}, \mathrm{CaZn}_{11}$ and CaZn at three different temperature ranges of $190-390^{\circ} \mathrm{C}, 390-590$ ${ }^{\circ} \mathrm{C}$ and $>590{ }^{\circ} \mathrm{C}$, respectively. The experimental reaction can be predicted from the in-situ XRD data as follows, which shows the presence of excess $\mathrm{CaH}_{2}$.

$\mathrm{CaH}_{2}+3 \mathrm{Zn} \rightarrow \frac{3}{13} \mathrm{CaZn}_{13}+\frac{10}{13} \mathrm{CaH}_{2}+\frac{3}{13} \mathrm{H}_{2}(\mathrm{~g})$

$\frac{3}{13} \mathrm{CaZn}_{13}+\frac{10}{13} \mathrm{CaH}_{2} \rightarrow \frac{3}{11} \mathrm{CaZn}_{11}+\frac{8}{11} \mathrm{CaH}_{2}+\frac{6}{143} \mathrm{H}_{2(\mathrm{~g})}$

$\frac{3}{11} \mathrm{CaZn}_{11}+\frac{8}{11} \mathrm{CaH}_{2} \rightarrow \frac{3}{5} \mathrm{CaZn}_{5}+\frac{2}{5} \mathrm{CaH}_{2}+\frac{18}{55} \mathrm{H}_{2}(\mathrm{~g})$

\section{Thermodynamic Calculations}

As the ex-situ XRD pattern of $\mathrm{CaH}_{2}$-3Zn after the TPD measurement at $830{ }^{\circ} \mathrm{C}$ did not exhibit any solid calcium-zinc alloy present in the decomposed sample, $\mathrm{PCl}$ measurements were performed at temperatures below $630^{\circ} \mathrm{C}$. The measurements were carried out at 565, 580, 600 and $614{ }^{\circ} \mathrm{C}$ (Fig. 7 a). The corresponding van't Hoff plot (Fig. $7 \mathrm{~b}$ ) was constructed by plotting the midpoint values from the first plateau region of each $\mathrm{PCl}$ measurement to acquire the enthalpy and entropy of reaction. The optimized form (no excess $\mathrm{CaH}_{2}$ ) of the above mentioned three reactions can be written as follows:

$\mathrm{CaH}_{2}+13 \mathrm{Zn} \rightarrow \mathrm{CaZn}_{13}+\mathrm{H}_{2}$ (g) 


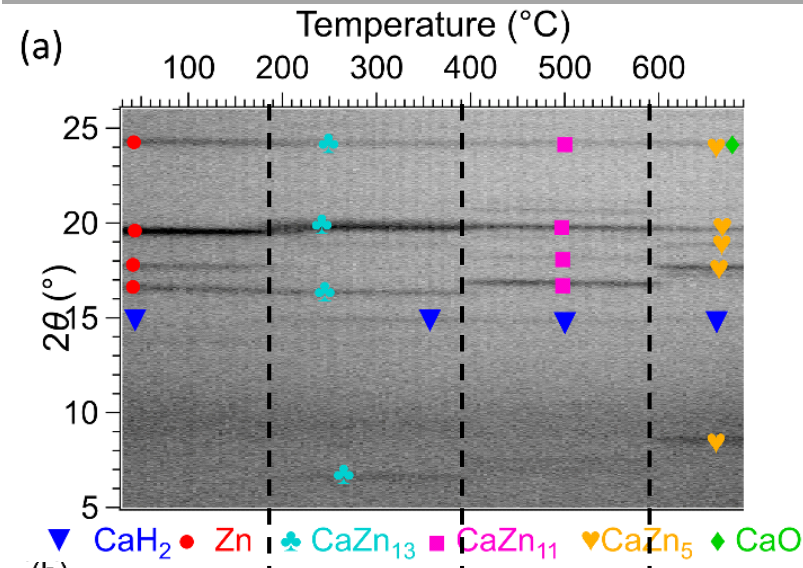

(b)

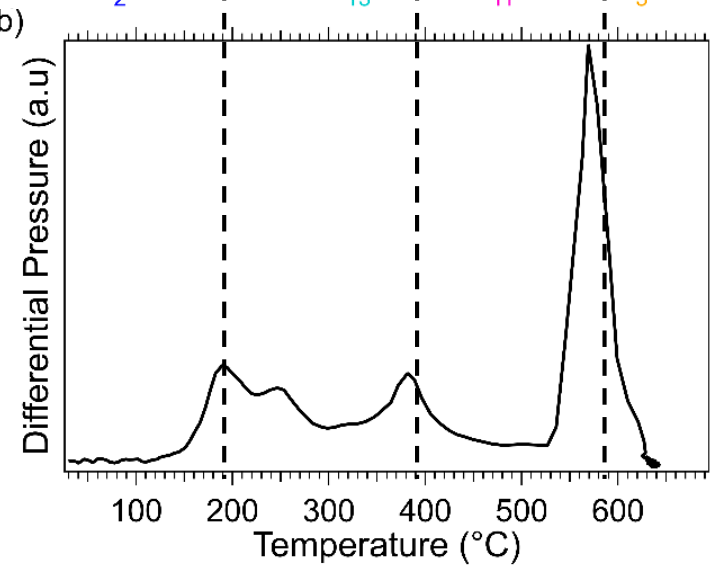

Fig. 6 (a) In-situ XRD patterns of $\mathrm{CaH}_{2}-3 \mathrm{Zn}$ from room temperature to $690^{\circ} \mathrm{C}$ (Mo $\mathrm{K} \alpha$ of $\lambda=0.7093 \AA$ ). (b) Differential TPD profiles of $\mathrm{CaH}_{2}-3 \mathrm{Zn}$ from room temperature to $640^{\circ} \mathrm{C}$.

$$
\begin{aligned}
& \mathrm{CaH}_{2}+11 \mathrm{Zn} \rightarrow \mathrm{CaZn}_{11}+\mathrm{H}_{2}(\mathrm{~g}) \\
& \mathrm{CaH}_{2}+\frac{5}{6} \mathrm{CaZn}_{11} \rightarrow \frac{11}{6} \mathrm{CaZn}_{5}+\mathrm{H}_{2}(\mathrm{~g})
\end{aligned}
$$

The corresponding enthalpy and entropy of the optimized reaction (5), obtained from first plateau as shown in Figure a, were calculated as $\Delta H_{\text {des }}=131.5 \pm 4.0 \mathrm{~kJ} . \mathrm{mol}^{-1} \mathrm{H}_{2}, \Delta S_{\text {des }}=151.1$ $\pm 4.0 \mathrm{~J} \cdot \mathrm{K}^{-1} \cdot \mathrm{mol}^{-1} \mathrm{H}_{2}$, respectively. Therefore, the equilibrium desorption temperature at 1 bar pressure is $T_{\text {des }}=\Delta H / \Delta S=597$ $\pm 35{ }^{\circ} \mathrm{C}$. The pressure curves of each $\mathrm{PCl}$ measurement show that thermodynamic equilibrium was reached for each of the 3 $\mathrm{h}$ desorption steps, indicating fast reaction kinetics (Fig. S3). The existence of two plateau regions in the $\mathrm{PCl}$ measurements is evident from Fig. 7 a. The second plateau region is not accurately measured due to (i) zinc evaporation (rate is high at higher temperatures and also depends on time exposed at that temperature) and (ii) limitation of the Sievert's apparatus to achieve very low pressure increments ( $<1 \mathrm{mbar})$. The formation of $\mathrm{CaZn}_{11}$ from reaction (5) followed by $\mathrm{CaZn}_{5}$ from reaction (6) during the $\mathrm{PCl}$ measurements were confirmed using ex-situ $X R D$. Fig. $8 a$ and $b$ show the XRD patterns of $\mathrm{CaH}_{2}-3 \mathrm{Zn}$ confirmed $\mathrm{CaZn}_{11}$ to be the main phase with only minor $\mathrm{CaZn}_{5}$ peaks present, whereas Fig. $8 \mathrm{~b}$ shows that all CaZn $\mathrm{n}_{11}$ peaks have been replaced with $\mathrm{CaZn}_{5}$ peaks formed during the second equilibrium pressure region. These XRD findings confirm the reactions given above $(4-6)$.
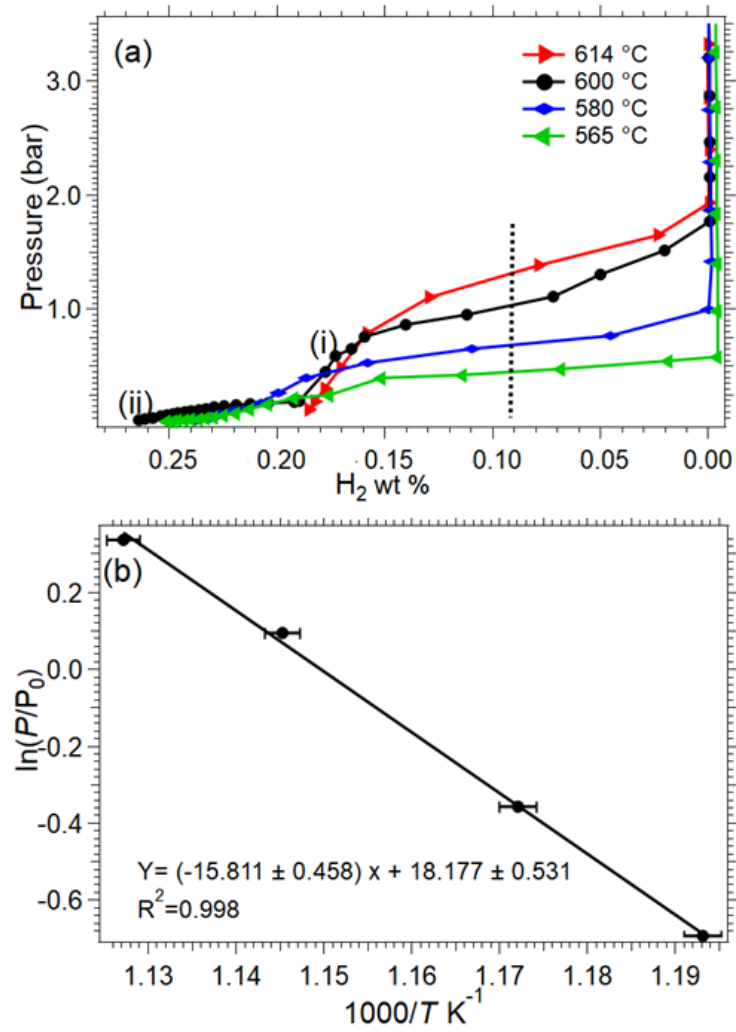

Fig. 7 (a) Pressure Composition Isotherms of $\mathrm{CaH}_{2}-3 \mathrm{Zn}$ between $565^{\circ} \mathrm{C}$ (green), $580{ }^{\circ} \mathrm{C}$ (blue), $600{ }^{\circ} \mathrm{C}$ (black) and $614^{\circ} \mathrm{C}$ (red) and (b) the corresponding van't Hoff plot.

\section{Cycling Studies}

$\mathrm{CaH}_{2}-3 \mathrm{Zn}$ was cycled at $580^{\circ} \mathrm{C}$, which follows the proposed optimized reaction expressed in eq. (5), to assess its $\mathrm{H}_{2}$ cycling capacity and thermochemical reversibility. This temperature was chosen in order to reduce the $\mathrm{Zn}$ evaporation rate from the sample. Fig. 9 illustrates the ten $\mathrm{H}_{2}$ desorption and absorption cycles showing good thermochemical reversibility overall. Each desorption and absorption step was 3 and $5 \mathrm{hrs}$, respectively. It is evident from Fig. 9 that the kinetics of the desorption reaction are faster than absorption. However, none of the reactions were completed within the allocated step time. The evaporation of $\mathrm{Zn}$ from the formed

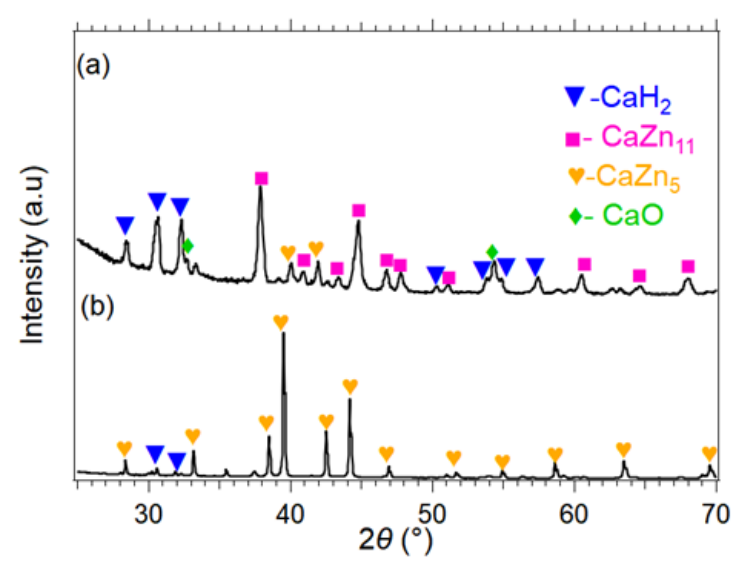

Fig. 8 Ex-situ XRD patterns of $\mathrm{CaH}_{2}-3 \mathrm{Zn}$ in the marked regions (a) at (i) and (b) at (ii) in the Fig. 7(a) from the $\mathrm{PCl}$ measurement at $600{ }^{\circ} \mathrm{C}\left(\mathrm{Cu} \mathrm{K}{ }_{\alpha}, \lambda=1.5418 \AA\right)$. 


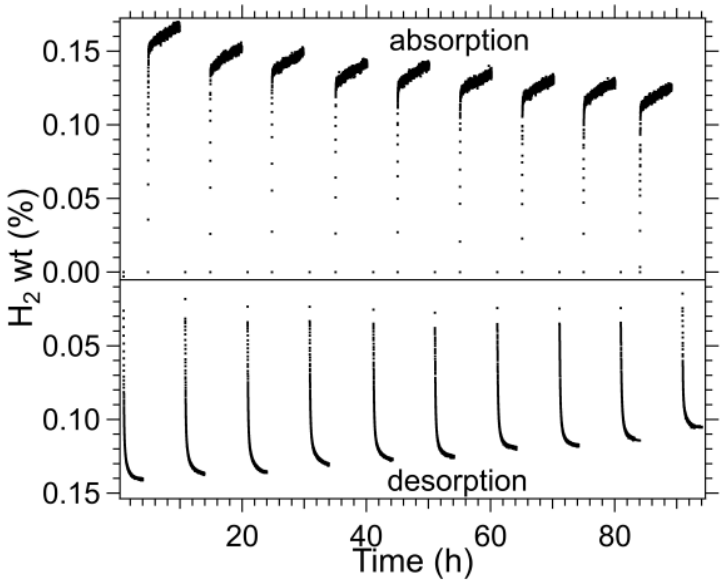

Fig. $9 \mathrm{H}_{2}$ desorption and absorption cycles of the $\mathrm{CaH}_{2}-3 \mathrm{Zn}$ mixture at $580^{\circ} \mathrm{C}$.

calcium zinc alloy during cycling was also confirmed from the presence of $\mathrm{Zn}$ metal deposition on the colder regions of the reactor. Therefore, after the completion of the $10^{\text {th }}$ cycle, $80 \%$ of its initial capacity was retained. The cycling capacity of $\mathrm{CaH}_{2}-3 \mathrm{Zn}$ may be enhanced by improving the design of the sample holder so that it can contain the evaporated $\mathrm{Zn}$ and also by initially synthesizing with 1:11 molar ratio of $\mathrm{CaH}_{2}: \mathrm{Zn}$. This may result in a complete desorption and absorption reaction upon cycling within the allocated waiting times.

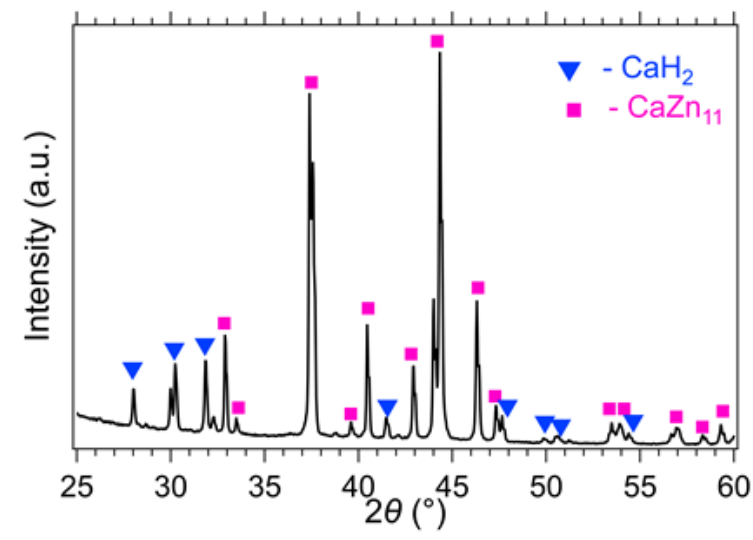

Fig. 10 Ex-situ XRD pattern of the $\mathrm{CaH}_{2}-3 \mathrm{Zn}$ mixture as prepared after cycling at 580 ${ }^{\circ} \mathrm{C}(\mathrm{Cu} \mathrm{K \alpha}, \lambda=1.5418 \AA$ A $)$

Also, it may allow more cycles without degradation as commercial thermochemical storage system requires a cycling reliability of up to 10000 cycles over a 30 year lifespan for CSP plants. An ex-situ XRD pattern (Figure 10) was obtained after the $10^{\text {th }}$ desorption cycle, confirming that $\mathrm{CaZn}_{11}$ was the main crystalline phase present in the decomposed samples, as previously confirmed from TPD, PCT and insitu XRD studies.

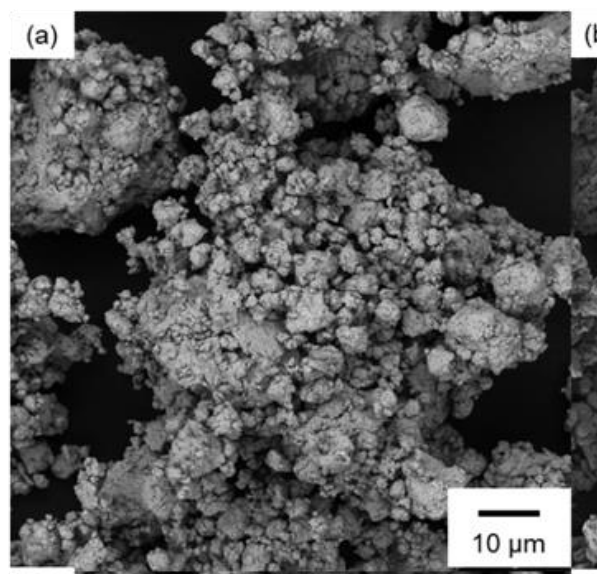

\section{(d)}

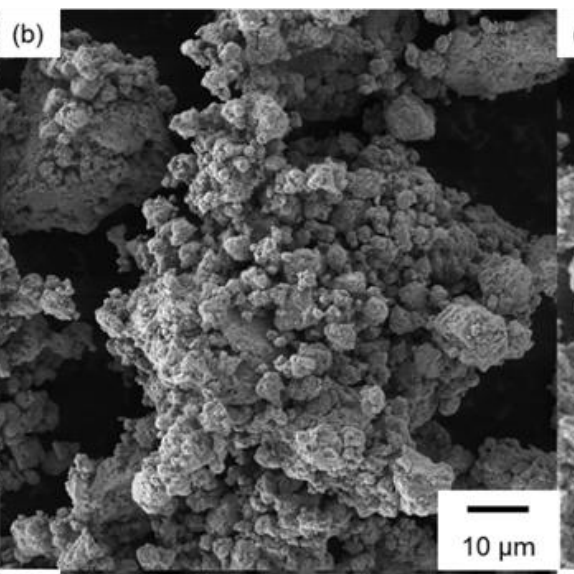

(e)
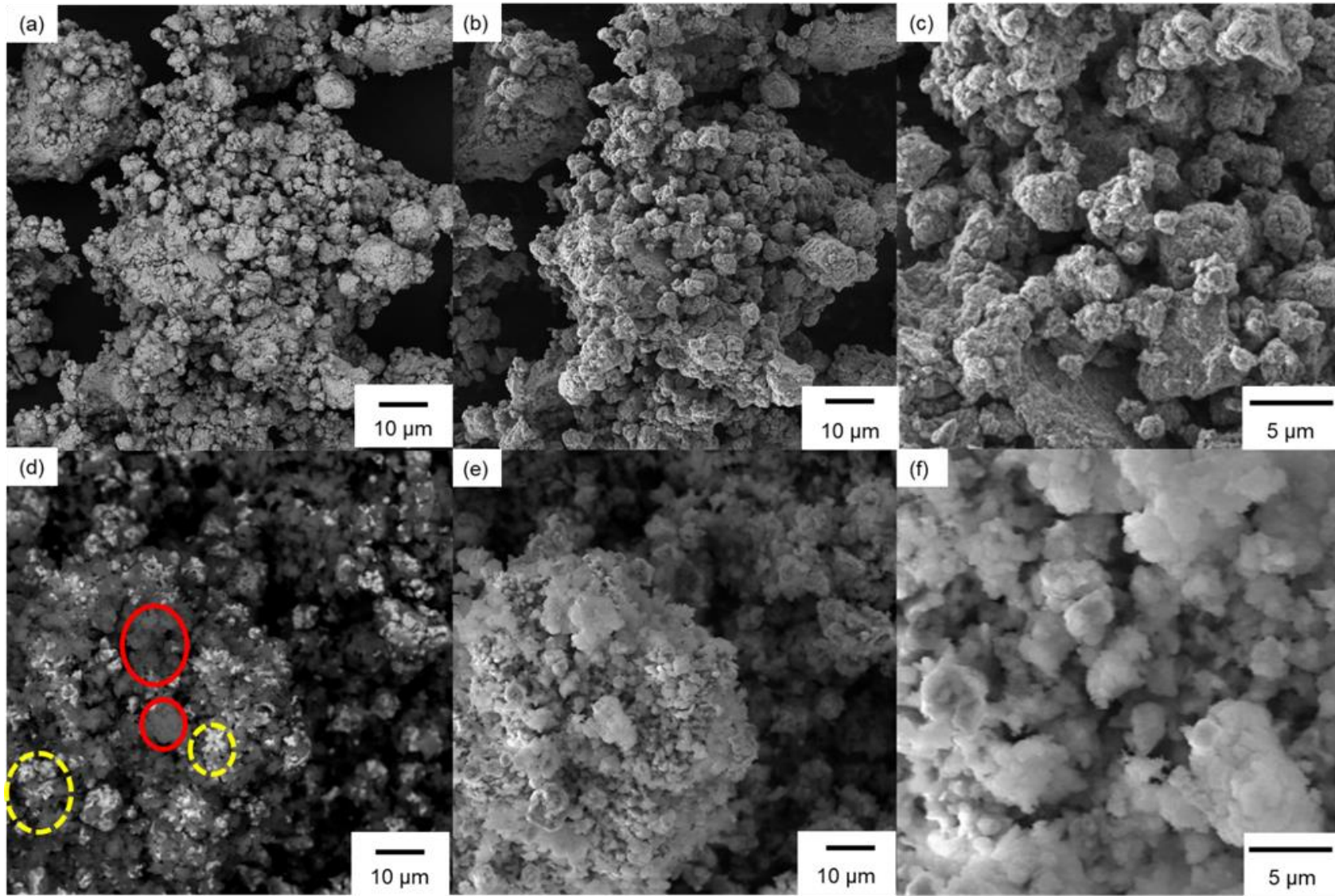

(f)

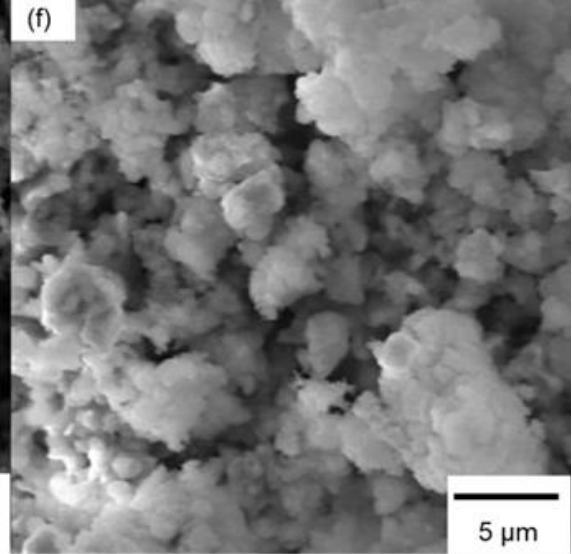

$5 \mu \mathrm{m}$

Fig. 11 SEM micrographs of the $\mathrm{CaH}_{2}-3 \mathrm{Zn}$ mixture using (a) back scattered electrons, (b, c) secondary electrons before cycling, and (d) back scattered and (e, f) secondary electrons after 10 cycles at $580^{\circ} \mathrm{C}$. 


\section{Morphological Studies}

SEM micrographs of $\mathrm{CaH}_{2}-3 \mathrm{Zn}$ before and after cycling are presented in Fig. $11 \mathrm{a}-\mathrm{c}$ and Fig. $11 \mathrm{~d}-\mathrm{f}$, respectively. It is evident from Fig. 11 a, obtained using backscattered electrons, that $\mathrm{CaH}_{2}$ and $\mathrm{Zn}$ are evenly distributed through the sample creating a homogenous powder after ball-milling. No distinctive bright and dark areas were observed in the micrograph that may have been created due to areas with inhomogeneous distributions of particles with excessively different atomic number, as observed in Fig. $11 \mathrm{~d}$ after cycling is performed. Specifically, the bright areas in Fig. $11 \mathrm{~d}$ indicated with yellow dashed circles are areas rich in $\mathrm{Zn}$, whereas the dark areas indicated with red circles are $\mathrm{Ca}$ rich, as confirmed by their associated EDS spectra (Fig. S4). To study the morphological differences before and after cycling, Fig. 11 b, c and 11 e, f were obtained using secondary electrons. It can be seen from Fig. 11 $\mathrm{c}$ and $\mathrm{f}$ that the powder particles before and after cycling are relatively the same size and the particles did not sinter or melt upon heating, as often is the case with other metal hydrides at temperatures above $500{ }^{\circ} \mathrm{C} .^{2}$

\section{Cost}

A cost comparison of the present system with other destabilized $\mathrm{CaH}_{2}$ systems and molten salt is listed in Table 1 . The cost of the raw material $\left(\mathrm{CaH}_{2}-11 \mathrm{Zn}\right)$ is currently estimated as $\$ 55 /$ $\mathrm{kWh}_{\mathrm{th}}, 19,40$ which is higher than molten salts and other destabilized $\mathrm{CaH}_{2}$ systems, such as $\mathrm{Al}$ and $\mathrm{Al}_{2} \mathrm{O}_{3}$ while significantly less compared with $\mathrm{LiBH}_{4}$ as shown in Table 1.43-44 However, the $\mathrm{CaH}_{2}-11 \mathrm{Zn}$ system possesses high enthalpy of reaction and relatively low operating pressure at the working temperature ( 1 bar $\mathrm{H}_{2}$ pressure at $600^{\circ} \mathrm{C}$ ) compared with the $\mathrm{CaH}_{2}$-Al system (62 bar $\mathrm{H}_{2}$ pressure at $700{ }^{\circ} \mathrm{C}$ )..$^{2,41}$ Overall the high cost, multistep reactions and $\mathrm{Zn}$ evaporation issues makes the $\mathrm{CaH}_{2}-3 \mathrm{Zn}$ system challenging to use as a commercial thermochemical storage material.

Table 1. Cost Comparison Study of $\mathrm{CaH}_{2}$-3Zn System with Pure $\mathrm{CaH}_{2}$, other $\mathrm{CaH}_{2}$ Destabilized Systems and Molten Salt in the CSP Scenario*.

\begin{tabular}{|c|c|c|c|c|c|c|c|c|}
\hline TES Material & $\begin{array}{c}\Delta \mathrm{H} \\
\mathrm{kJ} \cdot \mathrm{mol}^{-1} \mathrm{H}_{2}\end{array}$ & $\begin{array}{c}\Delta \mathrm{H} \\
\mathrm{kJ} / \mathrm{kg}\end{array}$ & US \$/ ton & $\begin{array}{l}\text { US \$/ kWh- } \\
\text { thermal }\end{array}$ & $\mathrm{T}\left({ }^{\circ} \mathrm{C}\right)$ & P (bar) & $\begin{array}{c}\text { Mass } \\
\text { required } \\
\text { tonnes }^{+}\end{array}$ & Ref. \\
\hline $\mathrm{CaH}_{2}$ & 207.9 & 4939 & 6000 & 4.4 & 1000 & 1.2 & 265 & 2,19 \\
\hline $\mathrm{CaH} 2+11 \mathrm{Zn}$ & 131 & 172 & 2649 & 55.4 & 597 & 1 & 8920 & 40 \\
\hline $3 \mathrm{CaH}_{2}+2 \mathrm{Al}_{2} \mathrm{O}_{3}$ & 100 & 909 & 2460 & 9.7 & 636 & 1 & 1650 & 23 \\
\hline $\mathrm{CaH}_{2}+2 \mathrm{Al}$ & 84 & 874 & 3631 & 14.9 & 700 & 62 & 1660 & $2,23,41-42$ \\
\hline $\mathrm{CaH}_{2}+6 \mathrm{LiBH}_{4}$ & 60 & 347 & 190500 & 1976 & 450 & 10 & 4960 & $43-44$ \\
\hline $\begin{array}{c}\text { Molten salt } \\
\left(40 \mathrm{NaNO}_{3}: 60 \mathrm{KNO}_{3}\right)\end{array}$ & 39 & 413 & 630 & 5.8 & 565 & - & 5250 & 19 \\
\hline
\end{tabular}

\section{Conclusions}

This study has developed a novel approach to thermodynamically destabilize $\mathrm{CaH}_{2}$ by adding low cost $\mathrm{Zn}$ metal in a 1:3 molar ratio, and investigate its potential as a TES material for third generation CSP plants. In-situ XRD diffraction studies showed the formation of three different calcium zinc alloys, CaZn $\mathrm{n}_{13}, \mathrm{CaZn}_{11}$ and $\mathrm{CaZn}_{5}$, at 190,390 and $590{ }^{\circ} \mathrm{C}$, respectively. The enthalpy and entropy of formation of $\mathrm{CaH}_{2-}$ $3 \mathrm{Zn}$ system was found to be $\Delta H_{\text {des }}=131 \pm 4 \mathrm{~kJ} \cdot \mathrm{mol}^{-1} \mathrm{H}_{2}, \Delta S_{\text {des }}=$ $151 \pm 4 \mathrm{~J} \cdot \mathrm{K}^{-1} \cdot \mathrm{mol}^{-1} \mathrm{H}_{2}$, respectively. The $\mathrm{CaH}_{2}-3 \mathrm{Zn}$ system's operating condition was found to be $597 \pm 35{ }^{\circ} \mathrm{C}$ at 1 bar of $\mathrm{H}_{2}$ pressure. Cycling studies of the material over the first step of the reaction show reasonable thermochemical reversibility over 10 cycles. SEM studies before and after cycling confirmed no significant sintering of the sample upon heating. The cost of the raw material was estimated as $\$ 55 / \mathrm{kWh}_{\mathrm{th}}$. The destabilization of $\mathrm{CaH}_{2}$ with $\mathrm{Zn}$ proves that thermodynamic destabilization can be achieved, but lower cost destabilizing agents must be found.
It is challenging to predict the optimal reaction pathways for these destabilization reactions due to unreliable thermodynamic predictions for several reaction products.

\section{Conflicts of interest}

There are no conflicts to declare.

\section{Acknowledgements}

C.E.B., M.P., T.D.H. and M.V.S. acknowledge the financial support of the Global Innovation Linkage (GIL73589). C.E.B. acknowledges the financial support of ARC Linkage grant LP150100730, and ARC LIEF grants LE0775551 and LE0989180, which enabled the TPD and $\mathrm{PCl}$ measurements to be undertaken. M.V.S. acknowledges the financial support of the UCD Ad Astra Fellowship, M.P. acknowledges the financial support of the Australian Research Council (ARC) Future Fellowship (FT160100303). C.E.B. acknowledge the financial support of the ARC for the ARC LIEF grant LE170100199, which 
enabled the in-situ XRD measurements. The authors acknowledge the technical assistance of Matthew Rowles and the facilities of the Microscopy \& Microanalysis Facility of the John de Laeter Centre at Curtin University.

\section{References}

1 Murphy, C.; Sun, Y.; Cole, W. J.; Maclaurin, G. J.; Mehos, M. S.; Turchi, C. S. The Potential Role of Concentrating Solar Power within the Context of DoE's 2030 Solar Cost Targets; National Renewable Energy Lab. NREL/TP-6A20-7191, 2019.

2 Manickam, K.; Mistry, P.; Walker, G.; Grant, D.; Buckley, C. E.; Humphries, T. D.; Paskevicius, M.; Jensen, T.; Albert, R.; Peinecke, K., Future Perspectives of Thermal Energy Storage with Metal Hydrides. International Journal of Hydrogen Energy 2019, 44, 7738-7745.

3 Pelay, U.; Luo, L.; Fan, Y.; Stitou, D.; Rood, M., Thermal Energy Storage Systems for Concentrated Solar Power Plants. Renewable and Sustainable Energy Reviews 2017, 79, 82-100.

4 Chen, X.; Zhang, Z.; Qi, C.; Ling, X.; Peng, H., State of the Art on the High-Temperature Thermochemical Energy Storage Systems. Energy conversion and management 2018, 177, 792815.

5 Carrillo, A. J.; González-Aguilar, J.; Romero, M.; Coronado, J. M., Solar Energy on Demand: A Review on High Temperature Thermochemical Heat Storage Systems and Materials. Chemical reviews 2019, 119, 4777-4816.

6 US Department of Energy, D.O.E. Sunshot Vision Study. (accessed Jun 02, 2020).

7 The Potential Role of Concentrating Solar Power within the Context of Doe's 2030 Solar Cost Targets (accessed Jun, 2020)

8 Ho, C. K., A Review of High-Temperature Particle Receivers for Concentrating Solar Power. Applied Thermal Engineering 2016, 109, 958-969.

9 Valverde, J. M.; Barea-Lopez, M.; Perejon, A.; SanchezJimenez, P. E.; Perez-Maqueda, L. A., Effect of Thermal Pretreatment and Nanosilica Addition on Limestone Performance at Calcium-Looping Conditions for Thermochemical Energy Storage of Concentrated Solar Power. Energy \& Fuels 2017, 31, 4226-4236.

10 Harries, D. N.; Paskevicius, M.; Sheppard, D. A.; Price, T. E. C.; Buckley, C. E., Concentrating Solar Thermal Heat Storage Using Metal Hydrides. Proceedings of the IEEE 2011, 100, 539549.

11 Pardo, P.; Deydier, A.; Anxionnaz-Minvielle, Z.; Rougé, S.; Cabassud, M.; Cognet, P., A Review on High Temperature Thermochemical Heat Energy Storage. Renewable and Sustainable Energy Reviews 2014, 32, 591-610.

12 Ervin, G., Solar Heat Storage Using Chemical Reactions. Journal of solid state chemistry 1977, 22, 51-61.

13 Gil, A.; Medrano, M.; Martorell, I.; Lázaro, A.; Dolado, P.; Zalba, B.; Cabeza, L. F., State of the Art on High Temperature Thermal Energy Storage for Power Generation. Part 1Concepts, Materials and Modellization. Renewable and Sustainable Energy Reviews 2010, 14, 31-55.

14 Lai, Q.; Paskevicius, M.; Sheppard, D. A.; Buckley, C. E.; Thornton, A. W.; Hill, M. R.; Gu, Q.; Mao, J.; Huang, Z.; Liu, H. K., Hydrogen Storage Materials for Mobile and Stationary Applications: Current State of the Art. ChemSusChem 2015, 8, 2789-2825

15 Sheppard, D.; Corgnale, C.; Hardy, B.; Motyka, T.; Zidan, R.; Paskevicius, M.; Buckley, C., Hydriding Characteristics of $\mathrm{NaMgH}_{2} \mathrm{~F}$ with Preliminary Technical and Cost Evaluation of Magnesium-Based Metal Hydride Materials for Concentrating Solar Power Thermal Storage. RSC Advances 2014, 4, 2655226562.
16 M. Hirscher, V. A. Yartys, M. Baricco, J. B. von Colbe, D. Blanchard, R. C. Bowman, D. P. Broom, C. E. Buckley, F. Chang, P. Chen, Y. W. Cho, J. C. Crivello, F. Cuevas, W. I. F. David, P. E. de Jongh, R. V. Denys, M. Dornheim, M. Felderhoff, Y. Filinchuk, G. E. Froudakis, D. M. Grant, E. M. Gray, B. C. Hauback, T. He, T. D. Humphries, T. R. Jensen, S. Kim, Y. Kojima, M. Latroche, H. W. Li, M. V. Lototskyy, J. W. Makepeace, K. T. Moller, L. Naheed, P. Ngene, D. Noreus, M. M. Nygard, S. I. Orimo, M. Paskevicius, L. Pasquini, D. B. Ravnsbaek, M. V. Sofianos, T. J. Udovic, T. Vegge, G. S. Walker, C. J. Webb, C. Weidenthaler and C. Zlotea, Journal of Alloys and Compounds, 2020, 827, 153548.

17 Rönnebro, E. C.; Whyatt, G.; Powell, M.; Westman, M.; Zheng, F. R.; Fang, Z. Z., Metal Hydrides for High-Temperature Power Generation. Energies 2015, 8, 8406-8430.

18 Sheppard, D.; Paskevicius, M.; Humphries, T.; Felderhoff, M.; Capurso, G.; von Colbe, J. B.; Dornheim, M.; Klassen, T.; Ward, P.; Teprovich, J., Metal Hydrides for Concentrating Solar Thermal Power Energy Storage. Applied Physics A 2016, 122, 395.

19 Humphries, T. D.; Møller, K. T.; Rickard, W. D.; Sofianos, M. V.; Liu, S.; Buckley, C. E.; Paskevicius, M., Dolomite: A Low Cost Thermochemical Energy Storage Material. Journal of Materials Chemistry A 2019, 7, 1206-1215.

20 Curtis, R.; Chiotti, P., Thermodynamic Properties of Calcium Hydride1. The Journal of Physical Chemistry 1963, 67, 10611065.

21 Peterson, D.; Fattore, V., Calcium-Calcium Hydride Phase System1. The Journal of Physical Chemistry 1961, 65, 2062 2064.

22 Sofianos, M. V.; Randall, S.; Paskevicius, M.; Aguey-Zinsou, K.F.; Rowles, M. R.; Humphries, T. D.; Buckley, C. E., Exploring Halide Destabilised Calcium Hydride as a High-Temperature Thermal Battery. Journal of Alloys and Compounds 2020, 819, 153340.

23 Balakrishnan, s.; Sofianos, M. V.; Paskevicius, M.; Rowles, M. R.; Buckley, C. E., Destabilised Calcium Hydride as a Promising High-Temperature Thermal Battery. The Journal of Physical Chemistry C 2020.

24 Vajo, J. J.; Olson, G. L., Hydrogen Storage in Destabilized Chemical Systems. Scripta Materialia 2007, 56, 829-834.

25 Okamoto, H., Ca-Zn (Calcium-Zinc). Journal of Phase Equilibria and Diffusion 2013, 34, 171-171.

26 Messing, A.; Adams, M.; Steunenberg, R. Contribution to the Phase Diagram Calcium-Zinc; Argonne National Lab., III.: 1962.

27 Vapor Pressure Calculator. https://www.iap.tuwien.ac.at/www/surface/vapor_pressure (accessed May 20, 2020)

28 Rietveld, H., A Profile Refinement Method for Nuclear and Magnetic Structures. Journal of applied Crystallography 1969, 2, 65-71.

29 Coelho, A. A., Topas and Topas-Academic: An Optimization Program Integrating Computer Algebra and Crystallographic Objects Written in C++. Journal of Applied Crystallography 2018, 51, 210-218.

30 Gražulis, S.; Daškevič, A.; Merkys, A.; Chateigner, D.; Lutterotti, L.; Quiros, M.; Serebryanaya, N. R.; Moeck, P.; Downs, R. T.; Le Bail, A., Crystallography Open Database (Cod): An Open-Access Collection of Crystal Structures and Platform for World-Wide Collaboration. Nucleic acids research 2011 40, D420-D427.

31 Pathak, P.; Vasavada, N., Thermal Expansion of Nacl, Kcl and Csbr by X-Ray Diffraction and the Law of Corresponding States. Acta Crystallographica Section A: Crystal Physics, Diffraction, Theoretical and General Crystallography 1970, 26, 655-658.

32 Hu, J.; Cai, W.; Li, C.; Gan, Y.; Chen, L., In Situ X-Ray Diffraction Study of the Thermal Expansion of Silver Nanoparticles in 
Ambient Air and Vacuum. Applied Physics Letters 2005, 86, 151915.

33 Hansen, B. R.; Møller, K. T.; Paskevicius, M.; Dippel, A.-C.; Walter, P.; Webb, C. J.; Pistidda, C.; Bergemann, N.; Dornheim, M.; Klassen, T., In Situ X-Ray Diffraction Environments for High-Pressure Reactions. Journal of Applied Crystallography 2015, 48, 1234-1241.

34 SRS. RGA Windows Software v.3.2. https://Www.Thinksrs.Com/Products/Vac.html_accessed August 18, 2020).

35 Sheppard, D. A.; Paskevicius, M.; Javadian, P.; Davies, I. J.; Buckley, C. E., Methods for Accurate High-Temperature Sieverts-Type Hydrogen Measurements of Metal Hydrides. Journal of Alloys and Compounds 2019, 787, 1225-1237.

36 Alonso, J. A.; Retuerto, M.; Sanchez-Benitez, J.; FernándezDíaz, M. T., Crystal Structure and Bond Valence of $\mathrm{CaH}_{2}$ from Neutron Powder Diffraction Data. Zeitschrift für Kristallographie-Crystalline Materials 2010, 225, 225-229.

37 Chiotti, P.; Hecht, R., Thermodynamic Properties of the Calcium-Zinc System. Transactions of the Metallurgical Society of AIME 1967, 239, 536-541.

38 Itkin, V.; Alcock, C., The Ca-Zn (Calcium-Zinc) System. Bulletin of Alloy Phase Diagrams 1990, 11, 328-333.

39 Hodge, W.; Jaffe, R.; Gonser, B. Calcium and Calcium-Base Alloys; Battelle Memorial Inst., Columbus, $\mathrm{OH}$, Project MX-791 Contr. W33-038-ac-14105, 1949.

$40 \mathrm{Zn}$ Metal

Prices. https://markets.businessinsider.com/commodities/zinc-price (Accessed Apr 20, 2020).

41 Ward, P. A.; Teprovich Jr, J. A.; Liu, Y.; He, J.; Zidan, R., High Temperature Thermal Energy Storage in the $\mathrm{CaAl}_{2}$ System. Journal of Alloys and Compounds 2018, 735, 2611-2615.

42 Veleckis, E., Application of the Hydrogen Titration Method to a Thermodynamic Investigation of Solid Al-Ca Alloys. Journal of the Less Common Metals 1981, 80, 241-255.

$43 \mathrm{Li}, \mathrm{Y}$.; Li, P.; Qu, X., Investigation on $\mathrm{LiBH}_{4}-\mathrm{CaH}_{2}$ Composite and Its Potential for Thermal Energy Storage. Scientific reports 2017, 7, 41754.

$44 \mathrm{LiBH}_{4}$ Prices.

https://www.sigmaaldrich.com/catalog/search?term $=$ LiBH4\& interface $=\mathrm{All} \& \mathrm{~N}=0 \&$ mode $=$ partialmax $\&$ lang $=$ en $\&$ region $=\mathrm{A}$ U\&focus=product (Accessed Apr 20, 2020). 